\title{
EFfects of IRRIGated Rice SowINg SEASON AND IMAZAPYR + IMAZAPIC TIME OF APPLICATION ON RICE GRAIN YIELD AND RED Rice MANAGEMENT ${ }^{1}$
}

\author{
Efeito da Época de semeadura de Arroz Irrigado e do Momento de Aplicação de \\ Imazapyr+Imazapic no Rendimento de Grãos de Arroz e no Manejo do Arroz-Vermelho
}

\author{
SARTORI, G.M.S. ${ }^{2}$, MARCHESAN, E. ${ }^{3}$, AZEVEDO, C.F. ${ }^{4}$, FILHO, A.C. ${ }^{5}$, ROSO, R. ${ }^{6}$, COELHO, L.L. ${ }^{7}$, \\ and OLIVEIRA, M.L. ${ }^{8}$
}

\begin{abstract}
Irrigated rice sowing season and red rice competition are among the main factors affecting grain yield. The objective of this work was to evaluate the sowing date of irrigated rice and moments of application of the herbicide imazapyr + imazapic to control red rice management and irrigated rice grain yield. Eight experiments were performed at the following dates $(09 / 30,10 / 19,11 / 08$ and 12/01) for the 2010/2011 harvest season and $(09 / 27,10 / 17$, $11 / 08$ and 12/05) for the 2011/2012 harvest season. The treatments were: application of the herbicide imazapyr + imazapic at doses of $105+35 \mathrm{~g} \mathrm{ha}^{-1}$ in pre-emergence (PRE); $52.5+17.5 \mathrm{~g} \mathrm{ha}^{-1}$ in pre-emergence and 52.5+17.5 $\mathrm{g} \mathrm{ha}^{-1}$ in post-emergence (PRE + POST); and $105+35 \mathrm{~g} \mathrm{ha}^{-1}$ in post- emergence (POST), and a control without application and no weeding. The cultivar Puitá Inta CL was used and a randomized block design with four replicates. A joint analysis of the experiments was carried out. There was less emergence of red rice and higher grain yield of the irrigated rice at the early periods (09/30/10 and 09/27/11), with 10,578 and $8,653 \mathrm{~kg} \mathrm{ha}{ }^{-1}$, respectively. At the end of the season $(12 / 01 / 10$ and 12/05/11), there was greater reduction of the red rice seed bank. Sowing at the beginning of the recommended period provided more irrigated rice grain yield. The application of imazapyr + imazapic at a dose of 52.5+17.5 $\mathrm{g} \mathrm{ha}^{-1}$ in PRE $+52.5+17.5 \mathrm{~g} \mathrm{ha}^{-1} \mathrm{POST}$, and $105+35 \mathrm{~g} \mathrm{ha}^{-1}$ only in PRE and POST was effective in the control of red rice.
\end{abstract}

Keywords: weed, herbicide, chemical control, temperature, solar radiation, Oryza sativa.

\begin{abstract}
RESUMO - A época de semeadura de arroz irrigado e a competição com arroz-vermelho estão entre os principais fatores que alteram o rendimento de grãos da cultura. O objetivo deste estudo foi avaliar épocas de semeadura do arroz irrigado e dos momentos de aplicação do herbicida imazapyr+imazapic no controle de arroz-vermelho e no rendimento de grãos de arroz irrigado. Realizaram-se oito experimentos nas seguintes épocas: (30/09, 19/10, 08/11 e 01/12) safra 2010/11 e (27/09, 17/ 10, 08/11 e 05/12) safra 2011/12. Os tratamentos avaliados foram: aplicação do herbicida imazapyr+imazapic nas doses de 105+35 $\mathrm{g} \mathrm{ha}^{-1}$ em pré-emergência (PRE); 52,5+17,5 $\mathrm{g}$ ha ${ }^{-1}$ em préemergência e 52,5+1 7,5 $\mathrm{g}$ ha-1 em pós-emergência (PRE+POS); e 105+35 g ha-1 em pós-emergência (POS), além de uma testemunha sem aplicação e sem capina. O cultivar utilizado foi Puitá Inta CL, e o delineamento utilizado foi blocos ao acaso em quatro repetições. Realizou-se análise conjunta dos experimentos em cada safra. Ocorreu menor emergência de arroz-vermelho e maior rendimento de grãos de arroz irrigado no início da época (30/09/10 e 27/09/11), com 10.578 e $8.653 \mathrm{~kg} \mathrm{ha-1,}$ respectivamente. No final daépoca (01/12/10 e 05/12/11), houve maior redução do banco de sementes
\end{abstract}

Recebido para publicação em 15.8.2012 e aprovado em 24.12.2012.

2 Agricultural Engineer, Master's student in Crop Sciences, Department of Plant Science, Center of Agricultural Sciences (CCR Centro de Ciências Rurais), Universidade Federal de Santa Maria - UFSM, <gersonmss@yahoo.com.br>; ${ }^{3}$ Dr. Professor, Department of Plant Science, CCR, UFSM, <eniomarchesan@gmail.com>; ${ }^{4}$ Undergraduate in Agronomy, Department of Plant Science, CCR, UFSM, <cristian.az@hotmail.com>; ${ }^{5}$ Dr. Professor, Department of Plant Science, CCR, UFSM, $<$ alberto.cargnelutti.filho@gmail.com>; ${ }^{6}$ Undergraduate in Agronomy, Department of Plant Science, CCR,UFSM, <rodrigoroso@yahoo.com.br>; ${ }^{7}$ Undergraduate in Agronomy, Department of Plant Science, CCR, UFSM,<lucas_1_c@ahotmail.com>; ${ }^{8}$ Undergraduate in Agronomy, Department of Plant Science, CCR,UFSM, <mauriciodeoliveira8@hotmail.com>. 
do arroz-vermelho. A semeadura no início da época recomendada proporciona maior rendimento de grãos de arrozirrigado. A aplicação de imazapyr+imazapic nas doses de 52, 5+17,5 $\mathrm{g} \mathrm{ha}$ em $^{-1} \mathrm{PRE}+$ 52,5+17,5 $\mathrm{g} \mathrm{ha}^{-1}$ POS e de 105+35 $\mathrm{g} \mathrm{ha}^{-1}$ somente em PRE e POS foi eficiente no controle do arroz-vermelho.

Palavras-chave: planta daninha, herbicida, controle químico, temperatura, radiação solar, Oryza sativa.

\section{INTRODUCTION}

Rice sowing season plays a significant role in crop yield potential, since it affects the response of other management practices. According to Freitas et al. (2008), the intersection of rice flowering and grain filling time with the period of highest solar radiation availability is what determines when rice sowing season will occur, once optimal conditions of temperature and solar radiation are key to raising grain yield potential. According to Junior et al. (1995), the optimal values of air temperature and radiation around flowering are $25^{\circ} \mathrm{C}$ and $475 \mathrm{cal} \mathrm{cm}^{-2}$ day $^{-1}$, respectively.

However, low temperatures at microsporogenesis or high temperatures at anthesis can cause spikelet sterility, affecting crop yield (Farrell et al., 2006). According to Jagadish et al. (2007), temperatures above $35{ }^{\circ} \mathrm{C}$ at anthesis for more than one hour may reduce the fertility of spikelets on rice. Rang et al. (2011) have reported that rice response to elevated temperature differs according to its stage of development, with greater sensitivity in the reproductive phase.

According to Slaton et al. (2003) and Freitas et al. (2008), the highest grain yields of irrigated rice are found when sowing is carried out early in the recommended season and they tend to decrease when sowing is performed at the end of the season. Sowing time delay causes reduction in the number of panicles per square meter (Freitas et al., 2008). Moreover, when sowing time is anticipated, emergence and early establishment may be negatively impacted, mainly due to suboptimal air temperatures during this period (Slaton et al., 2003).

Besides influencing the yield potential of rice, sowing time, if considered independently, may contribute to a more efficient control of red rice, one of the most relevant weeds found in irrigated rice areas. According to Marchesan et al. (2010) and Marchesan et al. (2011), red rice affects grain yield, the quality of the final product, and the price paid for the product (Gealy et al. 2000).

There are options for the chemical control of red rice, which include the use of cultivars that are tolerant to herbicides from the imidazolinone group. However, due to the diversity of biotypes, red rice and cultivated rice crossing, seed dormancy (Burgos et al., 2008), differences in emergence onset, and speed and duration of emergence (Shivrain et al., 2009), it is difficult to control red rice.

Accordingly, sowing time may be a significant crop practice for the control of red rice, since early in the recommended season (September/October), air and soil temperatures are lower compared to late in the recommended season (November/December). Lower temperature conditions maintain red rice seed dormancy, reducing germination and plant emergence (Gianinetti \& Cohn, 2008; Young-Son Cho, 2010).

Shivrain et al. (2009) have reported that, in sowing conducted early in the recommended season, red rice competition is reduced when compared to sowing conducted late in the recommended season. According to Norsworthy \& Oliveira (2007), at the end of the recommended season, red rice emergence rate is increased due to higher temperatures, which provide rapid seedling emergence and establishment. Thus, there is a need to know the impact of sowing time, when associated with weather conditions such as temperature and solar radiation, on the dynamics of red rice and rice grain yield, in order to have a more efficient control of red rice. There is also a need to know the best time to apply these herbicides (imazapyr and imazapic) taking into account the time of sowing, because some 
works on this subject, for instance those of Santos et al. (2007) and Marchesan et al. (2011), have assessed herbicide application time in a single sowing period. However, it is important to assess the behavior of such application times at different sowing periods.

The hypothesis of this work is that in sowing carried out early in the recommended season, there is lower emergency of red rice and greater rice grain yield; and in sowing carried out late in the recommended season, there is great seed bank reduction. Thus, this study aimed to assess irrigated rice sowing periods and imazapic + imazapyr moments of application on the control of red rice and on irrigated rice grain yield.

\section{MATERIAL AND METHODS}

Eight experiments were conducted on growing seasons 2010/11 and 2011/12. The area was located in the physiographic region of the Central Region of the State of Rio Grande do Sul (RS), in the city of Santa Maria, where climate is characterized, according to the Köppen classification, as humid subtropical (Cfa), with no dry season, with mean temperature of the warmest month above $22{ }^{\circ} \mathrm{C}$ (Moreno, 1961).

The experiments were performed on soil classified as Eutrophic Haplic Planossolo Hapludalf belonging to the mapping unit of Vacacai (Embrapa, 2006), which exhibited the following physicochemical characteristics: clay $=18 \%, \mathrm{pH}_{\text {water }}(1: 1)=5.8, \mathrm{P}=7.6 \mathrm{mg} \mathrm{dm}^{-3}$, $\mathrm{K}=40 \mathrm{mg} \mathrm{dm}^{-3}, \mathrm{Ca}=6.1 \mathrm{cmol}_{\mathrm{c}} \mathrm{dm}^{-3}, \mathrm{Mg}=$ $1.8 \mathrm{cmol}_{\mathrm{c}} \mathrm{dm}^{-3}$, and $\mathrm{MO}=2.1 \%$.

The experiments consisted of the following sowing dates for Puitá Inta-CL rice: (09/30, $10 / 19,11 / 08$ and $12 / 01)$ for the $2010 / 11$ harvest, and $(09 / 27,10 / 17,11 / 08$ and $12 / 05)$ for the 2011/12 harvest. The sowing period, according to the agricultural zoning Puitá Inta$\mathrm{CL}$ in Santa Maria, goes from September 1 to November 20. However, the choice of sowing dates in this study aimed to represent the sowing period for the state of RS, which is from early September to mid-December, varying according to the cycle of each cultivar and to the cultivation region. The treatments examined were: Kifix $\mathbb{}($ imazapic + imazapyr) application at doses $105+35 \mathrm{~g} \mathrm{ha}^{-1}$ in pre-emergence (PRE), $52.5+17.5 \mathrm{~g} \mathrm{ha}^{-1}$ in pre-emergence, and $52.5+17.5 \mathrm{~g} \mathrm{ha}^{-1}$ in postemergence (PRE + POS) and $105+35 \mathrm{~g} \mathrm{ha}^{-1}$ in post-emergence (POS), in addition to control with no herbicide and weed free. The experimental design was randomized blocks with four replications. The PRE application was held in stage $S_{3}$ (emergence of prophyll from coleoptile) of rice, and the POS application was conducted one day before final irrigation in stage $\mathrm{V}_{3} / \mathrm{V}_{4}$, according to the scale of Counce et al. (2000). Also in stage S3 of irrigated rice, we applied glyphosate at $1.08 \mathrm{~kg} \mathrm{ha}^{-1}$ in all treatments, with the purpose of controlling all the red rice plants that had emerged in the period between sowing and grain formation.

We used irrigated rice cultivar Puitá Inta$\mathrm{CL}$, which has a mean cycle of 125 days, with $90 \mathrm{~kg} \mathrm{ha}{ }^{-1}$ seed, sown in row spacing of $0.17 \mathrm{~m}$, in minimum tillage system in the $2010 / 11$ harvest and in direct sowing in the 2011/12 harvest. Base fertilizer was $15 \mathrm{~kg} \mathrm{ha}^{-1}$ nitrogen (N), $45 \mathrm{~kg} \mathrm{ha}^{-1} \mathrm{P}_{2} \mathrm{O}_{5}$ and $90 \mathrm{~kg} \mathrm{ha}^{-1} \mathrm{~K}_{2} \mathrm{O}$, and the $\mathrm{N}$ dose was divided in quantities of $15 \mathrm{~kg} \mathrm{ha}^{-1}$ at sowing, $70 \mathrm{~kg} \mathrm{ha}^{-1}$ at tillering $\left(\mathrm{V}_{3} / \mathrm{V}_{4}\right)$ and $35 \mathrm{~kg} \mathrm{ha}^{-1}$ at panicle iniciation (RO).

The following evaluations were performed: red rice seed bank, determined before sowing to sowing times, by counting the number of red rice seeds in two subsamples of $0.2 \times 0.2 \mathrm{~m}$ in each portion at a depth of $7 \mathrm{~cm}$; number of red rice plants emerged in the range from PRE application to POS application, determined by counting emerged plants in two subsamples of $0.2 \times 0.2 \mathrm{~m}$ in each plot, later transformed into percentage in relation to seed bank; total number of desiccated plants up to the moment of each sowing date, determined by counting the number of red rice plants in $0.5 \times 0.5 \mathrm{~m}$ per plot of $5 \mathrm{~m} \mathrm{x} 1.53 \mathrm{~m}$.

Desiccations were conducted with glyphosate at $1.08 \mathrm{~kg} \mathrm{ha}^{-1}$, when red rice plants were in stage $V_{3} / V_{4}$. Seed bank reduction was determined by summing emerged plants from PRE to POS application with the total number of plants desiccated up to the moment of each sowing date, and transformed in percentage in relation to the seed bank.

Furthermore, was assessed the control of red rice by counting the number of red rice 
panicles in each plot, and transforming in percentage in relation to control.

Grain yield was estimated by manual harvesting of $4.16 \mathrm{~m}^{2}$ on crop area, when they reached mean moisture of $22 \%$. After sorting, cleaning and weighing of grain with shell, data were corrected to $13 \%$ moisture and converted to $\mathrm{kg} \mathrm{ha}^{-1}$. The number of panicles $\mathrm{m}^{-2}$ was determined by counting the panicles in a row meter, and in that same area we collected 15 panicles at harvest to estimate the number of grains per panicle, thousand grain weight and spikelet sterility.

The values of global solar radiation and air temperature were obtained from the meteorological station of the University of Santa Maria, available at the National Institute of Meteorology (INMET). Soil temperature was obtained using temperature sensor (model L34-108-EN) at a depth of $3 \mathrm{~cm}$ and recorded in data logger CR1000.

Results were submitted to analysis of variance, comparing in each crop the sowing dates of irrigated rice. Means were compared by Tukey test at $5 \%$ probability.

Data that referred to red rice seed bank reduction, red rice desiccated plants $\mathrm{m}^{-2}$, and red rice emergence were transformed to $y t=\sqrt{(y)+0.5}$.

\section{RESULTS AND DISCUSSION}

\section{0/11 Harvest}

There was interaction between sowing dates and times of herbicide application for all variables except for thousand grain weight and spikelet sterility (Table 1). The area where the experiment was conducted showed variation in red rice seed bank from 237 to 2533 seeds $\mathrm{m}^{-2}$, the largest seed bank noted in the area of the first and third sowing times: $09 / 30$ and $11 / 08$, respectively (Table 2 ).

At the beginning of the recommended sowing period (09/30 and 10/19) there was lower emergence of red rice when compared to late sowing period $(11 / 08$ and $12 / 01)$ (Table 2), indicating that sowing time plays a key role in the management of red rice, by having lower emergency of red rice early in the sowing period, thus, there is less competition and damage to irrigated rice.

This response may be related to the seed dormancy of red rice, due to the physiological immaturity of the embryo, once it is detached from the mother plant, and it may also present impermeability to gas cover and/ or imbalance of substances that promote and inhibit germination induced during the accumulation of dry seed weight (Filio, 2005), associated with lower air temperature (average temperature around $16{ }^{\circ} \mathrm{C}$ ) and soil (average temperature around $18{ }^{\circ} \mathrm{C}$ ) during the beginning of the recommended period (Figure 1A), which may have contributed to inhibit germination and emergence of large population of red rice in this area.

Young-Son Cho (2010) evaluated the effect of different temperatures in the day and night, represented by 15/10, 20/15, 25/20 and $30 / 25{ }^{\circ} \mathrm{C}$, and found on average a lower percentage of red rice germination in lower temperatures, with $25 / 20{ }^{\circ} \mathrm{C}$ as one in which there was best germination. According to this author, the percentage and speed of germination increase with increasing temperature. Gianinetti \& Cohn (2008), have observed greater red rice mean germination at 20 to $35{ }^{\circ} \mathrm{C}$, compared to 1 to $15{ }^{\circ} \mathrm{C}$, and optimum temperature for rice development from $25^{\circ} \mathrm{C}$ to $30{ }^{\circ} \mathrm{C}$ (Yoshida, 1981). According to Marcos Filho (2005), rice seeds overcome dormancy when exposed to high temperatures, and response speed is directly related to the increase in temperature.

Temperatures lower than this range $\left(25\right.$ to $\left.30^{\circ} \mathrm{C}\right)$ can cause cold stress, which is considered one of the most important abiotic stresses in rice, causing changes in germination, percentage of normal seedlings, coleoptile length, among other factors, mainly affecting the expression of isozymes, such as esterase and dehydrogenase enzyme, involved in seed germination (Mertz et al., 2009).

In sowings conducted at the end of the recommended period, the emergence rate of red rice was increased due to higher temperatures, which provide rapid seedling emergence (Norsworthy \& Oliveira, 2007). This emergence speed is very similar to rice, implying rapid establishment of biotopes 
Table 1 - Source of variation (SV), number of degrees of freedom (DF) and mean square estimates of the red rice seed bank (RRSB), red rice emergence (RRE), red rice desiccated plants (RRDP), red rice seed bank reduction (RRBR), control of red rice (CRR), grain yield (GY), number of panicles (NP), number of grains per panicle (NGP), thousand grain weight (TGW) and spikelet sterility (S) in the 2010/11 and 2011/12 harvests. Santa Maria, RS. 2012

\begin{tabular}{|c|c|c|c|c|c|c|}
\hline \multirow{3}{*}{ SV } & \multirow{3}{*}{$\mathrm{DF}$} & \multicolumn{5}{|c|}{ 2010/11 harvest } \\
\hline & & \multicolumn{5}{|c|}{ QM } \\
\hline & & RRSB & RRE & RRDP & RRBR & CRR \\
\hline $\mathrm{B}(\mathrm{A})$ & 12 & $141240.67^{*}$ & 0.67 & $19.11^{*}$ & 1.27 & 1.19 \\
\hline $\mathrm{A}$ & 3 & $11277164.81^{*}$ & $90.68^{*}$ & $705.95^{*}$ & $92.16^{*}$ & $64.45^{*}$ \\
\hline $\mathrm{D}$ & 3 & $614714.40^{*}$ & $1.64^{*}$ & $17.03^{*}$ & $2.52^{*}$ & $72.95^{*}$ \\
\hline$A * D$ & 9 & $415739.59^{*}$ & $2.71^{*}$ & $23.24^{*}$ & $3.81^{*}$ & $66.08^{*}$ \\
\hline error & 36 & 59242.46 & 0.38 & 4.29 & 0.85 & 1.27 \\
\hline \multicolumn{2}{|c|}{$\mathrm{CV} \%$} & 22.5 & 17.8 & 14.2 & 16.7 & 1.1 \\
\hline & & GY & NP & NGP & TGW & $S$ \\
\hline $\mathrm{B}(\mathrm{A})$ & 12 & 395115.84 & $12980.50^{*}$ & 20.82 & 0.73 & 2.66 \\
\hline $\mathrm{A}$ & 3 & $24700262.50^{*}$ & $214106.87^{*}$ & $192.99^{*}$ & $7.49^{*}$ & $25.30^{*}$ \\
\hline $\mathrm{D}$ & 3 & $11866878.34^{*}$ & $11438.39^{*}$ & $98.82^{*}$ & $3.02^{*}$ & $11.76^{*}$ \\
\hline$A^{*} D$ & 9 & $2657118.27^{*}$ & $22793.99^{*}$ & $125.66^{*}$ & $1.30^{\mathrm{ns}}$ & $5.29^{\mathrm{ns}}$ \\
\hline error & 36 & 324184.36 & 3488.36 & 28.61 & 0.94 & 2.68 \\
\hline \multicolumn{2}{|c|}{$\mathrm{CV} \%$} & 6.3 & 11.89 & 6.2 & 3.8 & 29.4 \\
\hline & & \multicolumn{5}{|c|}{ 2011/12 harvest } \\
\hline & & RRSB & RRE & RRDP & RRBR & CRR \\
\hline $\mathrm{B}(\mathrm{A})$ & 12 & 56.48 & 2.38 & 1.12 & 1.96 & 1.66 \\
\hline $\mathrm{A}$ & 3 & $1792.70^{*}$ & $28.02^{*}$ & $244.21^{*}$ & $129.87^{*}$ & $1.45^{\mathrm{ns}}$ \\
\hline $\mathrm{D}$ & 3 & $405.20^{*}$ & $3.44^{\mathrm{ns}}$ & $23.51^{*}$ & $1.62^{\mathrm{ns}}$ & $1.88^{\mathrm{ns}}$ \\
\hline$A^{*} \mathrm{D}$ & 9 & $73.07^{*}$ & $3.85^{*}$ & $6.48^{*}$ & $2.48^{\mathrm{ns}}$ & $1.58^{\mathrm{ns}}$ \\
\hline error & 36 & 33.79 & 1.58 & 3.21 & 1.96 & 1.65 \\
\hline \multicolumn{2}{|c|}{$\mathrm{CV} \%$} & 28.1 & 30.4 & 26.4 & 33.2 & 1.2 \\
\hline & & GY & $\mathrm{NP}$ & NGP & TGW & $S$ \\
\hline $\mathrm{B}(\mathrm{A})$ & 12 & 315332.68 & 4011.78 & 67.96 & 1.11 & 2.66 \\
\hline $\mathrm{A}$ & 3 & $4913070.01^{*}$ & $40796.55^{*}$ & $2677.80^{*}$ & $13.45^{*}$ & $36.61^{*}$ \\
\hline $\mathrm{D}$ & 3 & $6829406.68^{*}$ & $11385.75^{*}$ & $109.12^{\text {ns }}$ & $2.64^{*}$ & $2.78^{\mathrm{ns}}$ \\
\hline$A^{*} D$ & 9 & $2095265.29^{*}$ & $6284.66^{*}$ & $105.79^{\mathrm{ns}}$ & $1.07^{\mathrm{ns}}$ & $1.95^{\mathrm{ns}}$ \\
\hline error & 36 & 240082.29 & 2630.85 & 77.23 & 0.82 & 2.82 \\
\hline \multicolumn{2}{|c|}{$\mathrm{CV} \%$} & 5.9 & 10.2 & 13.9 & 3.8 & 22.4 \\
\hline
\end{tabular}

${ }^{*}$ Significant at $5 \%$ probability. ${ }^{\text {ns }}$ Non-significant. $\mathrm{B}=$ block; $\mathrm{A}=$ sowing seasons; $\mathrm{D}=$ times of application.

(Shivrain et al., 2009), which increases the potential for competition and damage to irrigated rice.

The greatest emergence of red rice at the end of the recommended period (11/08 and $12 / 01)$ provided high reduction of seed bank (Table 2): 54 to $91.6 \%$ in the last sowing date. This reduction of seed bank was due to longer time to perform desiccations of red rice seedlings that emerged in the area, with a higher number of seedlings desiccated: 553 and 289 seedlings $\mathrm{m}^{-2}$ at end of period $(11 / 8$ and 12/01), respectively, compared with 109 and 71 seedlings $\mathrm{m}^{-2}$ in the early period 09/30 and 10/19 respectively (Table 2).

Such sowing practice at the end of the recommended period may be an important alternative to guide decision-making when you want to use the strategy to reduce seed bank in areas infested with red rice. 
Table 2 - Red rice seed bank (RRSB), red rice emergence (RRE), number of red rice desiccated plants (RRDP), red rice seed bank reduction (RRBR), and control of red rice (CRR) as a function of sowing time and time of Kifix ${ }^{\circledR}$ (imazapic + imazapyr) application in cultivar Puitá Inta-CL. 2010/11 harvest. Santa Maria, RS. 2012

\begin{tabular}{|c|c|c|c|c|}
\hline \multirow[b]{2}{*}{ Times of sowing } & \multicolumn{4}{|c|}{ Times of application } \\
\hline & $\begin{array}{l}\text { Control group with no } \\
\text { application }\end{array}$ & $\mathrm{PRE}^{\#}$ & $\mathrm{PRE}+\mathrm{POS}$ & POS \\
\hline \multicolumn{5}{|c|}{ Red rice seed bank (RRSB) (seeds $\left.\mathrm{m}^{-2}\right)$} \\
\hline $09 / 30 / 2010$ & $2533 \mathrm{Aa}$ & $2179 \mathrm{ABa}$ & $1653 \mathrm{Cb}$ & $1842 \mathrm{BCa}$ \\
\hline $10 / 19 / 2010$ & $237^{\mathrm{NS}} \mathrm{d}$ & $342 \mathrm{c}$ & $247 \mathrm{c}$ & $269 \mathrm{c}$ \\
\hline $11 / 8 / 2010$ & $1704 \mathrm{Ab}$ & $1159 \mathrm{Bb}$ & $2137 \mathrm{Aa}$ & $1017 \mathrm{Bb}$ \\
\hline $12 / 1 / 2010$ & $779 \mathrm{Ac}$ & $422 \mathrm{ABc}$ & $525 \mathrm{ABc}$ & $262 \mathrm{Bc}$ \\
\hline Mean & 1313 & 1025 & 1140 & 847 \\
\hline $\mathrm{CV} \%$ & \multicolumn{4}{|c|}{22.5} \\
\hline \multicolumn{5}{|c|}{ Red rice emergence (RRE) $(\%)^{\frac{1}{1 /}}$} \\
\hline $9 / 30 / 2010$ & $1.1(0.8)^{*}{ }^{\mathrm{NS}} \mathrm{c}$ & $1.1(0.8) \mathrm{c}$ & $2.0(3.6) \mathrm{c}$ & $1.6(2.2) \mathrm{c}$ \\
\hline $10 / 19 / 2010$ & $1.5(2.6) \mathrm{Bbc}$ & $1.8(3.2) \mathrm{Bc}$ & $3.1(10.3) \mathrm{Abc}$ & $2.1(5.1) \mathrm{ABc}$ \\
\hline $11 / 8 / 2010$ & 7.9(63.8) Aa & $6.5(41.6) \mathrm{BCa}$ & $5.6(30.6) \mathrm{Ca}$ & $7.3(53.9) \mathrm{ABa}$ \\
\hline $12 / 1 / 2010$ & $2.5(5.9) \mathrm{Bb}$ & $3.3(11.1) \mathrm{ABb}$ & $3.4(11.8) \mathrm{ABb}$ & $4.5(19.8) \mathrm{Ab}$ \\
\hline Mean & 18.2 & 14.1 & 14.0 & 20.2 \\
\hline $\mathrm{CV} \%$ & \multicolumn{4}{|c|}{17.8} \\
\hline \multicolumn{5}{|c|}{ Red rice desiccated plants (RRDP) (plantas $\left.\mathrm{m}^{-2}\right)^{2 /}$} \\
\hline $9 / 30 / 2010$ & $8.9(83){ }^{\mathrm{NS}} \mathrm{b}$ & $9.8(97) \mathrm{b}$ & $10.9(121) \mathrm{c}$ & $11.4(133) \mathrm{c}$ \\
\hline $10 / 19 / 2010$ & $8.3(72){ }^{\mathrm{NS}} b$ & $7.6(57) b$ & $10.4(108) \mathrm{c}$ & $6.9(48) \mathrm{d}$ \\
\hline $11 / 8 / 2010$ & 19.7(399) $\mathrm{Ba}$ & 19.4(393) Ba & $27.0(765) \mathrm{Aa}$ & $25.5(654) \mathrm{Aa}$ \\
\hline $12 / 1 / 2010$ & $18.7(355)^{\mathrm{NS}} \mathrm{a}$ & $17.7(315) \mathrm{a}$ & $15.3(244) \mathrm{b}$ & $15.4(241) b$ \\
\hline Mean & 227 & 215 & 309 & 269 \\
\hline $\mathrm{CV} \%$ & \multicolumn{4}{|c|}{14.2} \\
\hline \multicolumn{5}{|c|}{ Red rice seed bank reduction (RRBR) $(\%)^{3 /}$} \\
\hline $9 / 30 / 2010$ & $2.2(4.4))^{\mathrm{NS}} \mathrm{c}$ & $2.3(4.9) \mathrm{c}$ & $2.8(7.3) \mathrm{b}$ & $2.6(6.4) \mathrm{c}$ \\
\hline $10 / 19 / 2010$ & 5.7(33.8) $\mathrm{ABb}$ & $4.8(23.6) \mathrm{Bb}$ & 6.7(44.9) Aa & $4.3(19.1) \mathrm{Bc}$ \\
\hline $11 / 8 / 2010$ & $4.6(22.2) \mathrm{Bb}$ & $5.7(33.0) \mathrm{ABb}$ & $5.9(35.3) \mathrm{ABa}$ & $7.3(54.7) \mathrm{Ab}$ \\
\hline $12 / 1 / 2010$ & 7.6(59.0) $\mathrm{Ba}$ & 8.7(77.3) $\mathrm{ABa}$ & 7.4(54.0) $\mathrm{Ba}$ & $9.6(91.6) \mathrm{Aa}$ \\
\hline Mean & 30 & 35 & 35 & 43 \\
\hline $\mathrm{CV} \%$ & \multicolumn{4}{|c|}{16.7} \\
\hline \multicolumn{5}{|c|}{ Control of red rice (CRR) $(\%)$} \\
\hline $9 / 30 / 2010$ & - & $99^{\mathrm{NS}} \mathrm{a}$ & $100^{\mathrm{ns}}$ & $100^{\mathrm{ns}}$ \\
\hline $10 / 19 / 2010$ & - & $100^{\mathrm{NS}} \mathrm{a}$ & 100 & 100 \\
\hline $11 / 8 / 2010$ & - & $86 \mathrm{Bb}$ & $100 \mathrm{~A}$ & $100 \mathrm{~A}$ \\
\hline $12 / 1 / 2010$ & - & $100^{\mathrm{NS}} \mathrm{a}$ & 100 & 100 \\
\hline Mean & & 96 & 100 & 100 \\
\hline $\mathrm{CV} \%$ & & & & \\
\hline
\end{tabular}

Variables with values $\dagger$ in parentheses indicate original values $\dagger$, averages not followed by the same letter, lowercase in column and uppercase in row, differ by Tukey test at $5 \%$ probability; ${ }^{N S}$ not significant in row; ns not significant in column ; ${ }^{1}$ percentage of red rice emergence in relation to seed bank in PRE to POS application; ${ }^{2}$ number of red rice desiccated plants from 09/23/2010 to the sowing date of each season, ${ }^{3}$ seed bank reduction in relation to red rice seed bank. ${ }^{*}$ Doses of imazapic + imazapyr were: $105+35 \mathrm{~g} \mathrm{ha}^{-1}(\mathrm{PRE})$, $52.5+17.5 \mathrm{~g} \mathrm{ha}^{-1}$ and $52.5+17.5 \mathrm{~g} \mathrm{ha}^{-1}$ (PRE+POS) and 105+35 $\mathrm{g} \mathrm{ha}^{-1}$ (POS).

With respect to the chemical control of red rice (Table 2), the POS application and the PRE + POS application were efficient, resulting in
100\% control. The PRE application alone showed lower efficiency in $11 / 08$, with $86 \%$ control, which can be explained by the greater 


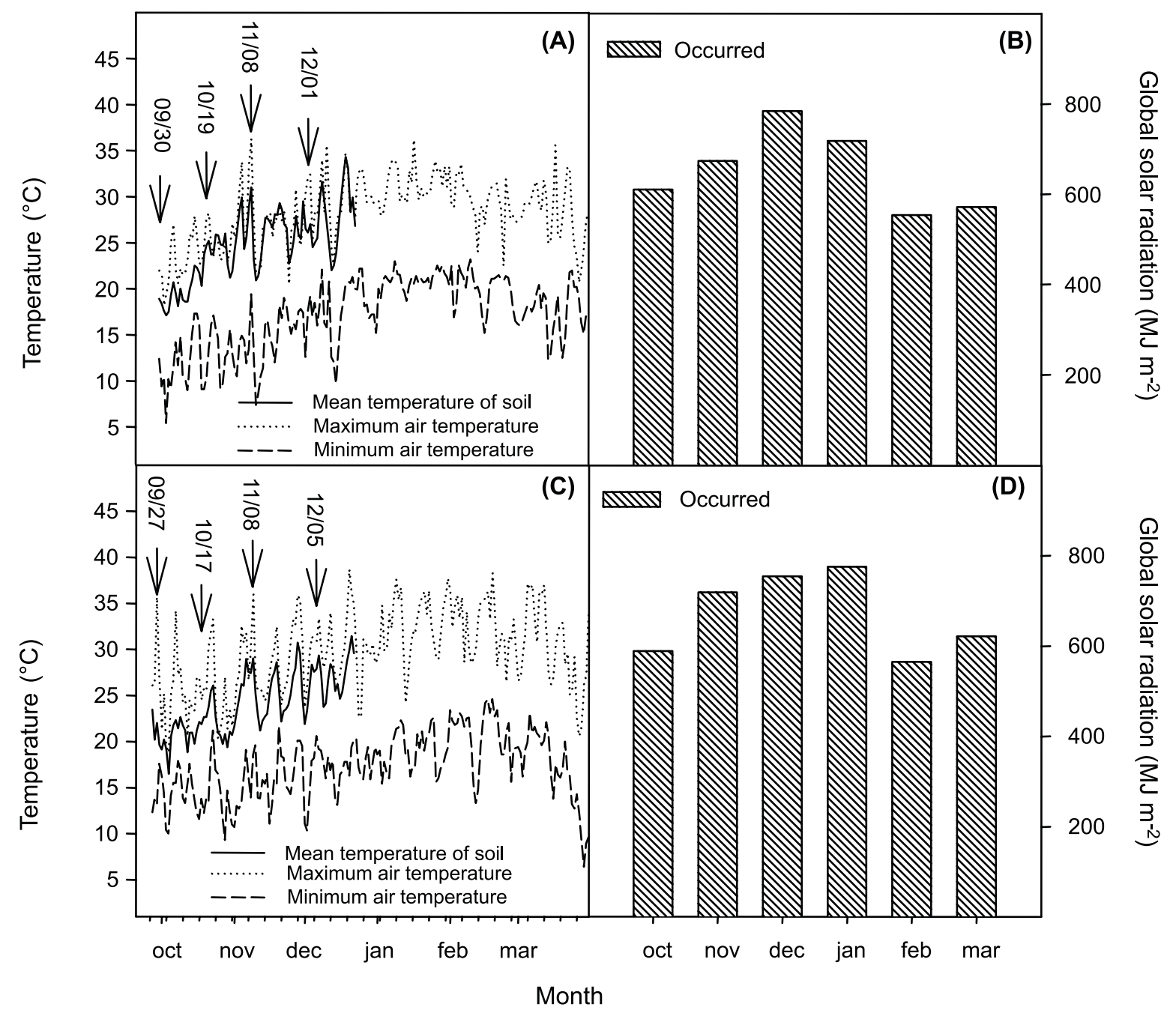

1/ Times of sowing.

Figure 1 - Mean temperature at $3 \mathrm{~cm}$ soil depth, maximum and minimum air temperature (Figure 1A, 2010/11 harvest) and (Figure 1B, 2011/12 harvest) and global solar radiation occurred in the 2010/11 harvest (Figure 1C) and in the 2011/12 harvest (Figure 1D). Santa Maria, RS. 2012.

seed bank (more seeds for the same amount of herbicide) in comparison to the areas that were performed in 10/19 and 12/01, in which seed bank was smaller. Moreover, at $11 / 08$, the conditions of air temperature and soil were greater (Figure 1A), which improved germination and emergence of red rice. This control efficiency of treatment in POS and PRE + POS is related to the fact that in the area where the experiment was conducted there are no biotypes resistant to the imidazolinone chemical group, plus it has perfect leveling of surface area and the proper management of irrigation. Furthermore, high efficiency in the control provided by the PRE + POS application or POS only, is due to the fact that the POS applications were performed on a day before the final irrigation. Thus, with the establishment of water depth, an anaerobic environment was formed, reducing one of the main mechanisms of dissipation of these herbicides from the imidazolinone group, which is the microbial degradation (Flint \& Witt, 1997; Madani et al. 2003; Alister \& Kogan 2005).

Machesan et al. (2010) have also reported that the POS application may decrease 
the biodegradation of herbicides due to anaerobic condition, which occurs with the establishment of irrigation after herbicide application. Another very important factor that may have contributed to greater efficiency in the control treatments that were applied in POS is auto-liming (soil chemical changes resulting from the reduction process), which occurs 15 to 20 days after the formation of water depth, raising the $\mathrm{pH}$ of acidic soils favoring dissociation of herbicides, making herbicides molecules available for plant uptake (Avila et al. 2006), since, with the presence of the carboxylic acid and the basic functional group of pyridine, imazapyr has three pKa values $(1.9,3.6$ and 11.4$)$, which is one of the characteristics that make the behavior of this herbicide in soil pH dependent (Firmino et al., 2008). Also, a study with imazaquin conducted by Oliveira et al. (2004) showed that with increasing $\mathrm{pH}$ reduction occurs Kd values (soil water partition coefficient) in all levels $(2-6 \%)$ of organic matter studied, with it, the adsorption is reduced due to the dominance of their shape anionic, becoming more available in the soil solution.

However, the herbicides of the chemical group of imidazolinones, when applied in PRE, may have a reduced efficiency because they can be degraded by microorganisms in greater quantities compared to POS application, whereas the application to the soil remains PRE for a longer period of time in aerobic condition, which is favorable to biodegradation. Thus, there can be reduction in the concentration of herbicide in the soil and therefore it can provide lower efficiency of control. One of the factors considered most important - responsible for the lower efficiency of herbicides when applied in PRE - that is, in conditions of lower $\mathrm{pH}$ of the soil, there may be adsorption of these herbicides to soil colloids (Bresnaham et al., 2000; Madani et al. 2003; Alister \& Kogan, 2005; Kraemer et al. 2009), which decreases the efficiency of control.

Corroborating the study, Marchesan et al. (2011), when assessing the control of red rice using chemical herbicides of the imidazolinone group imazethapyr $\left(75 \mathrm{~g} \mathrm{~L}^{-1}\right)$ + imazapic (25 $\mathrm{g} \mathrm{L}^{-1}$ ) (ready mix) at the recommended dose in Brazil, found no differences between application in PRE + POS and POS application only. Villa et al. (2006) have also evaluated the control of red rice in two rice varieties using imidazolinone herbicides at a dose of $75 \mathrm{~g} \mathrm{~L}^{-1}$ imazethapyr + $25 \mathrm{~g} \mathrm{~L}^{-1}$ of imazapic, and found that the split application of herbicide ( PRE + POS) using 75\% of the dose in PRE followed by $50 \%$ for POS, was the one which provided better control without causing loss of yield.

Santos et al. (2007) evaluated the efficiency of control of red rice provided by the use of formulated mixture (75 $\mathrm{g} \mathrm{L}^{-1}$ imazethapyr + $25 \mathrm{~g} \mathrm{~L}^{-1}$ of imazapic) and observed that the application of $52.5 \mathrm{~g} \mathrm{ha}^{-1}$ imazethapyr + $17.5 \mathrm{~g} \mathrm{ha}^{-1}$ in PRE imazapic followed by the same dose in POS, is more efficient when compared to the application of $75 \mathrm{~g} \mathrm{ha}^{-1}$ imazethapyr $+25 \mathrm{~g} \mathrm{ha}^{-1}$ PRE imazapic only, or only in POS.

Sowing dates have also affected the yield of irrigated rice (Table 3), with higher grain yield in the first season (09/30), ranging from $9,752 \mathrm{~kg} \mathrm{ha}^{-1}$, with no chemical control of red rice, to $11,258 \mathrm{~kg} \mathrm{ha}^{-1}$, when control was performed, and this was $(09 / 30)$ the best sowing time, to obtain higher yield. The highest grain yield occurred in this sowing season may be related to the coincidence that this was the period of more responsive plant behavior (flowering and grain filling) and the period of highest solar radiation availability in the months of December and January (Figure 1C), which was reflected in a higher number of panicles, higher thousand grain weight and lower spikelet sterility in relation to sowing dates at end of recommended period (Table 3 ). In sowing at the end of the recommended period $(12 / 01)$, the yield was $22 \%$ lower compared to the sowing of $09 / 30$, equivalent to a reduction of $38 \mathrm{~kg} \mathrm{ha}^{-1}$ day $^{-1}$ in the mean of treatments PRE, PRE + POS and POS.

These results support the work conducted in the state of Rio Grande do Sul by Freitas et al. (2008) in which they gained greater number of panicles and higher grain yield when rice was sown at the preferred date (11/ 02) compared to late recommended period (12/ 09). Besides the sowing date, another factor that affected grain yield was the presence of red rice. Comparing the first sowing date (09/ $30)$ with the other, there is a reduction of 11 , 
52 and $22 \%$ yield when chemical control was not performed (Table 3 ) to the second (10/19), third $(11 / 08)$ and fourth times $(12 / 01)$, respectively. This occurred because of greater emergence of red rice in the first sowing date.
The largest reduction in grain yield of the third season of sowing is related to the increased presence of red rice in the area, compared to the second and fourth seasons. These results show the great potential

Table 3 - Grain yield (GY) ( $\mathrm{kg} \mathrm{ha}^{-1}$ ), number of panicles (NP), number of grains per panicle (NGP), thousand grain weight (TGW) and spikelet sterility (S) as a function of sowing date and time of Kifix ${ }^{\circledR}$ (imazapic + imazapyr) applicationfor Puitá Inta-CL. 2010/ 11 harvest. Santa Maria, RS. 2012

\begin{tabular}{|c|c|c|c|c|}
\hline \multirow[b]{2}{*}{ Times of sowing } & \multicolumn{4}{|c|}{ Times of application } \\
\hline & $\begin{array}{l}\text { Control group with no } \\
\text { application }\end{array}$ & $\mathrm{PRE}^{\#}$ & PRE + POS & POS \\
\hline \multicolumn{5}{|c|}{ Grain yield (GY) $\left(\mathrm{kg} \mathrm{ha}^{-1}\right)$} \\
\hline 9/30/2010 & $9752 \mathrm{Ba}$ & $10650 \mathrm{ABa}$ & $11258 \mathrm{Aa}$ & $10654 \mathrm{ABa}$ \\
\hline $10 / 19 / 2010$ & $8658^{\mathrm{NS}} \mathrm{b}$ & $8973 \mathrm{~b}$ & $9469 \mathrm{~b}$ & $9602 \mathrm{ab}$ \\
\hline $11 / 8 / 2010$ & $4689 \mathrm{Bc}$ & $8718 \mathrm{Ab}$ & $8723 \mathrm{Ab}$ & $8786 \mathrm{Abc}$ \\
\hline $12 / 1 / 2010$ & $7621 \mathrm{Bb}$ & $8219 \mathrm{ABb}$ & $8881 \mathrm{Ab}$ & $8435 \mathrm{ABc}$ \\
\hline Mean & 7680 & 9140 & 9583 & 9369 \\
\hline $\mathrm{CV} \%$ & \multicolumn{4}{|c|}{6.3} \\
\hline \multicolumn{5}{|c|}{ Number of panicles (NP) $\left(\mathrm{m}^{-2}\right)$} \\
\hline $9 / 30 / 2010$ & $643^{\mathrm{NS}} \mathrm{a}$ & $571 \mathrm{a}$ & $671 \mathrm{a}$ & $650 \mathrm{a}$ \\
\hline $10 / 19 / 2010$ & $528 \mathrm{ABb}$ & $569 \mathrm{Aa}$ & $448 \mathrm{Bb}$ & $482 \mathrm{ABb}$ \\
\hline $11 / 8 / 2010$ & $466 \mathrm{Ab}$ & $229 \mathrm{Bb}$ & $279 \mathrm{Bc}$ & $428 \mathrm{Ab}$ \\
\hline $12 / 1 / 2010$ & $487^{\mathrm{NS}} \mathrm{b}$ & $565 \mathrm{a}$ & $479 \mathrm{~b}$ & $454 \mathrm{~b}$ \\
\hline Mean & 531 & 483.5 & 287.9 & 503 \\
\hline \multirow[t]{2}{*}{$\mathrm{CV} \%$} & \multicolumn{4}{|c|}{11.89} \\
\hline & \multicolumn{4}{|c|}{ Number of grains per panicle (NGP) } \\
\hline $9 / 30 / 2010$ & $73 \mathrm{Bc}$ & $86 \mathrm{Aa}$ & $82 \mathrm{AB}^{\mathrm{ns}}$ & $87 \mathrm{~A}^{\mathrm{ns}}$ \\
\hline $10 / 19 / 2010$ & $94^{\mathrm{NS}} \mathrm{a}$ & $86 \mathrm{a}$ & 89 & 86 \\
\hline $11 / 8 / 2010$ & $81 \mathrm{ABbc}$ & $74 \mathrm{Bb}$ & $90 \mathrm{~A}$ & $89 \mathrm{~A}$ \\
\hline $12 / 1 / 2010$ & $85^{\mathrm{NS}} \mathrm{ab}$ & $88 \mathrm{a}$ & 86 & 90 \\
\hline Mean & 83 & 83 & 86 & 88 \\
\hline $\mathrm{CV} \%$ & \multicolumn{4}{|c|}{6.2} \\
\hline \multicolumn{2}{|c|}{ Times of sowing } & \multicolumn{2}{|c|}{ TGW $(\mathrm{g})$} & $\mathrm{S} \%$ \\
\hline \multicolumn{2}{|l|}{$9 / 30 / 2010$} & \multicolumn{2}{|c|}{$26 \mathrm{a}$} & $4.1 \mathrm{c}$ \\
\hline $10 / 19 / 2010$ & & & & $4.9 \mathrm{bc}$ \\
\hline $11 / 8 / 2010$ & & & & $6.9 \mathrm{a}$ \\
\hline $12 / 1 / 2010$ & & & & $6.4 \mathrm{ab}$ \\
\hline Times & plication & & & \\
\hline Control group with $\mathrm{n}$ & lication & & & $5.5 \mathrm{ab}$ \\
\hline PRE & & & & $4.9 \mathrm{~b}$ \\
\hline PRE + POS & & & & $5.0 \mathrm{~b}$ \\
\hline POS & & & & $6.8 \mathrm{a}$ \\
\hline & & 2 & & 5.5 \\
\hline & & 3 & & 9.4 \\
\hline
\end{tabular}

Averages not followed by the same letter, lowercase in column and uppercase in row, differ by Tukey test at $5 \%$ probability; Ns not significant in row; ns not significant in column * Doses of imazapic + imazapyr were: $105+35 \mathrm{~g} \mathrm{ha}^{-1}(\mathrm{PRE}), 52.5+17.5 \mathrm{~g} \mathrm{ha}^{-1}$ and $52.5+17.5 \mathrm{~g} \mathrm{ha}^{-1}(\mathrm{PRE}+\mathrm{POS})$, and $105+35 \mathrm{~g} \mathrm{ha}^{-1}$ (POS). 
of damage to red rice with cultivated rice, according to Fischer \& Ramirez (1993), 24 panicles $\mathrm{m}^{-2}$ red rice can cause losses of $50 \%$ in grain yield.

Generally, for this harvest, sowing time affected the yield of crop, with higher grain yield when seeding is performed early in the recommended date $(09 / 30)$, due to better conditions of temperature and solar radiation in the reproductive period of the culture. However, from the second $(10 / 19)$ until the fourth season $(1 / 12)$ there was no significant reduction in grain yield, as the average values of minimum air temperature were 25, 23 and $21^{\circ} \mathrm{C}$ for the months of January, February and March (reproductive period of culture), respectively, the average maximum for the same months were 26,24 and $23{ }^{\circ} \mathrm{C}$ (Figure 1A), respectively, without compromising spikelet fertility and hence grain yield. Even though the lowest accumulation of solar radiation, during the reproductive period of crop in such sowing dates, may explain the lower yields when compared to the first season (09/30).

\section{$2011 / 12$ Harvest}

In this season, there was interaction between sowing dates and times of herbicide application with seed bank, emergence of red rice, number of red rice desiccated seedlings, grain yield and number of panicles $\mathrm{m}^{-2}$ (Table 1). There was decrease in seed bank of red rice (Table 4) in the area compared to the 2010/11 harvest, with variation from 62 to 1,791 seeds $\mathrm{m}^{-2}$, and the largest seed bank were in the area of the first and third seasons.

In general, except for control with no herbicide application, the results of red rice emergence (Table 4) follow similar behavior to the 2010/11 harvest, with increased emergence of red rice with the delay of sowing time with mean emergence from 4 to $18 \%$ at the beginning of the recommended period $(09 / 27$ and 10/17), respectively, and 35 and $26 \%$ at the end of the emergency period $(8 / 11$ and $5 / 12)$, respectively. The lowest emergence of red rice early in the recommended period, compared to times at the end of the period can be related to lower temperatures at the beginning of the period (Figure $1 \mathrm{~B}$ ) and the air temperature around $15{ }^{\circ} \mathrm{C}$ to average minimum $25{ }^{\circ} \mathrm{C}$ and the average maximum around $20{ }^{\circ} \mathrm{C}$, the seed of red rice have been induced to secondary dormancy because in work performed by Gianinetti \& Cohn (2008), when evaluating the germination of red rice under different temperature conditions at $15{ }^{\circ} \mathrm{C}$, the population of red rice seed dormancy was induced in secondary. According to these authors, the percentage of seeds that are induced in secondary dormancy decreases with increasing temperature $\left(15-25^{\circ} \mathrm{C}\right)$, in the optimum germination temperature $\left(30^{\circ} \mathrm{C}\right)$ biotypes had minimal dormancy, explaining in part the results. The highest emergence of red rice at late period may be related to higher temperatures occurring during this period (Figure 1B), because with increasing temperature, germination processes occur faster than inducing dormancy (Gianinetti \& Cohn, 2008).

As for the control without herbicide, this season there was no difference in emergence of red rice between sowing dates, emergency occurring high even in the beginning of the sowing period recommended $(09 / 27)$. This may be related to the fact that in the 2010/11 season was not held control of red rice plants in this treatment (control without herbicide and weed free), promoting feedback seedbank red rice. Moreover, this harvest, the seeds of red rice resulting from the 2010/11 season were on the road surface, because, unlike the 2010/11 season, in which the system used was the minimum tillage with tillage after harvest this crop system was used direct seeding, so there is no incorporation of the seeds in the soil profile.

Thus, red rice seeds remained on the soil surface, becoming more exposed to weather conditions such as temperature, moisture, oxygen, and other factors that may have contributed to overcoming dormancy and consequently led to the germination of seeds. Fogliatto et al. (2011), when evaluating the germination of a population of red rice stored under different conditions in the field, observed that the seeds on the soil surface showed rapid release of dormancy and germination. In the United States, Noldin et al. (2006) found a higher percentage of seed dormancy of red rice seeds buried at $12 \mathrm{~cm}$ depth, compared to seeds exposed to soil surface. 
Table 4 - Red rice seed bank (RRSB), red rice emergence (RRE), number of red rice desiccated plants (RRDP), red rice seed bank reduction (RRBR), and control of red rice (CRR) as a function of sowing time and time of Kifix ${ }^{\circledR}$ (imazapic + imazapyr) application in cultivar Puitá Inta-CL. 2011/12 harvest. Santa Maria, RS. 2012

\begin{tabular}{|c|c|c|c|c|}
\hline \multirow[b]{2}{*}{ Times of sowing } & \multicolumn{4}{|c|}{ Times of application } \\
\hline & $\begin{array}{l}\text { Control group with no } \\
\text { application }\end{array}$ & $\mathrm{PRE}^{\#}$ & PRE + POS & POS \\
\hline \multicolumn{5}{|c|}{ Red rice seed bank (RRSB) (seeds $\mathrm{m}^{-2}$ ) } \\
\hline $9 / 27 / 2011$ & $1787 \mathrm{Aa}$ & $906 \mathrm{Ba}$ & $956 \mathrm{ABa}$ & $853 \mathrm{Ba}$ \\
\hline $10 / 17 / 2011$ & $275^{\mathrm{NS}} \mathrm{b}$ & $269 \mathrm{bc}$ & $112 \mathrm{bc}$ & $200 \mathrm{~b}$ \\
\hline $11 / 8 / 2011$ & $1791 \mathrm{Aa}$ & $687 \mathrm{Bab}$ & $384 \mathrm{Bb}$ & $462 \mathrm{Bab}$ \\
\hline $12 / 5 / 2011$ & $159^{\mathrm{NS}} \mathrm{b}$ & $100 \mathrm{c}$ & $62 \mathrm{c}$ & $97 \mathrm{~b}$ \\
\hline Mean & 1003 & 490 & 378 & 403 \\
\hline $\mathrm{CV} \%$ & \multicolumn{4}{|c|}{28.1} \\
\hline \multicolumn{5}{|c|}{ Red rice emergence (RRE) $(\%)^{1^{1 /}}$} \\
\hline $9 / 27 / 2011$ & $3.9(16.7)^{* \mathrm{NSns}}$ & $1.8(3.5) \mathrm{b}$ & $2.5(4.8) b$ & $1.8(3.2) \mathrm{b}$ \\
\hline $10 / 17 / 2011$ & $3.1(10.7)^{\mathrm{NS}}$ & $2.6(6.6) \mathrm{b}$ & $4.8(23.5) \mathrm{a}$ & $4.7(25.1) \mathrm{a}$ \\
\hline $11 / 8 / 2011$ & $5.0(24.6)^{\mathrm{NS}}$ & $6.2(39.5) \mathrm{a}$ & $5.7(34.6) \mathrm{a}$ & $5.4(31.0) \mathrm{a}$ \\
\hline $12 / 5 / 2011$ & 3.9(16.0) AB & $3.6(16.6) \mathrm{Bb}$ & $6.0(36.5) \mathrm{Aa}$ & $4.9(25.4) \mathrm{ABa}$ \\
\hline Mean & 17.0 & 16.5 & 24.8 & 21 \\
\hline $\mathrm{CV} \%$ & \multicolumn{4}{|c|}{30.4} \\
\hline \multicolumn{5}{|c|}{ Red rice desiccated plants (RRDP) (plantas $\left.\mathrm{m}^{-2}\right)^{\frac{2 /}{}}$} \\
\hline $9 / 27 / 2011$ & $4.8(24){ }^{\mathrm{NS}} \mathrm{b}$ & $3.6(10) \mathrm{c}$ & $3.3(12) b$ & $3.9(15) b$ \\
\hline $10 / 17 / 2011$ & $3.9(15)^{\mathrm{NS}} \mathrm{b}$ & $3.0(10) \mathrm{c}$ & $3.7(13) b$ & $2.0(3) \mathrm{b}$ \\
\hline $11 / 8 / 2011$ & $14.2(214) \mathrm{Aa}$ & $12.0(152) \mathrm{Aa}$ & $8.1(67) \mathrm{Ba}$ & $11.0(124) \mathrm{ABa}$ \\
\hline $12 / 5 / 2011$ & $11.3(129) \mathrm{Aa}$ & $7.2(51) \mathrm{Bb}$ & $8.4(71) \mathrm{ABa}$ & 7.7(60) Ba \\
\hline Mean & 95 & 55 & 40 & 50 \\
\hline $\mathrm{CV} \%$ & \multicolumn{4}{|c|}{26.4} \\
\hline \multicolumn{2}{|c|}{ Times of sowing } & \multicolumn{2}{|c|}{$\operatorname{RRBR}(\%)^{3 /}$} & CRR (\%) \\
\hline \multicolumn{2}{|l|}{$9 / 27 / 2011$} & \multicolumn{2}{|c|}{$1.3(1.5) \mathrm{d}$} & $99.8^{\mathrm{ns}}$ \\
\hline \multicolumn{2}{|l|}{$10 / 17 / 2011$} & $2.7(9.7$ & & 99.2 \\
\hline $11 / 8 / 2011$ & & $4.8(26$ & & 99.9 \\
\hline $12 / 5 / 2011$ & & $7.9(63$ & & 100 \\
\hline Times & plication & & & \\
\hline Control group with $n$ & lication & $3.9(22$ & & - \\
\hline PRE & & $4.2(23$ & & $99.3^{\mathrm{ns}}$ \\
\hline PRE + POS & & $4.7(25$ & & 100 \\
\hline POS & & $4.0(29$ & & 100 \\
\hline & & 25.2 & & 99.7 \\
\hline & & 33.2 & & 1.2 \\
\hline
\end{tabular}

Variables with values $\dagger$ in parentheses indicate original values $\dagger$, averages not followed by the same letter, lowercase in column and uppercase in row, differ by Tukey test at 5\% probability; Ns not significant in row; ns not significant in column ; ${ }^{1 /}$ percentage of red rice emergence in relation to seed bank in PRE to POS application; ${ }^{2 /}$ number of red rice desiccated plants from 9/20/2011 to the sowing date of each season, ${ }^{3} /$ seed bank reduction in relation to red rice seed bank. ${ }^{*}$ Doses of imazapic + imazapyr were: $105+35 \mathrm{~g} \mathrm{ha}{ }^{-1}(\mathrm{PRE})$, $2.5+17.5 \mathrm{~g} \mathrm{ha}^{-1}$ and $52.5+17.5 \mathrm{~g} \mathrm{ha}^{-1}$ (PRE+POS), and 105+35 $\mathrm{g} \mathrm{ha}^{-1}$ (POS).

For the variables red rice seed bank reduction and red rice control, there was no interaction between sowing dates and times of herbicide application (Table 1). At all times sowing decreased red rice seed bank (Table 4), which was lower in sowing dates performed at the beginning of the recommended period and higher at late period. This behavior is similar to what happened in the 2010/11 harvest. This further reduction of the seed bank of red 
rice in the late recommended period is due primarily to the longer period of time to control the seedlings that emerged during the period. In sowing dates early in the period, $(09 / 27$ and $10 / 17)$ in the average of treatments, 15 and 10 seedlings $\mathrm{m}^{-2}$ were desiccated, respectively, while in late period (11/08 and 12/05) that number was 139 and 78 seedlings $\mathrm{m}^{-2}$, respectively, which contributed to further reduction of seed bank (Table 4).

As for chemical control (Table 4) there was no significant control difference among PRE, PRE + POS and POS applications, with control average of $99.7 \%$ in the dates of application. As in the 2010/11 harvest, this control efficiency is due to appropriate irrigation management and the fact that the red rice biotypes present in the area are not resistant to the imidazolinone group of herbicides. In addition, this season had fewer red rice seeds in the seed bank compared to the 2010/11 season for the same amount of herbicide, explaining in part the efficiency of control at the time of application only in PRE. However, in absolute terms, was observed reduced control at the time of PRE application, which may in part be related to the adsorption

Table 5 - Grain yield (GY) $\left(\mathrm{kg} \mathrm{ha}^{-1}\right)$, number of panicles (NP), number of grains per panicle (NGP), thousand grain weight (TGW) and spikelet sterility (S) as a function of sowing date and time of Kifix ${ }^{\circledR}$ (imazapic + imazapyr) applicationfor Puitá Inta-CL. 2011/ 12 harvest. Santa Maria, RS. 2012

\begin{tabular}{|c|c|c|c|c|}
\hline \multirow[b]{2}{*}{ Times of sowing } & \multicolumn{4}{|c|}{ Times of application } \\
\hline & $\begin{array}{l}\text { Control group with no } \\
\text { application }\end{array}$ & $\mathrm{PRE}^{\#}$ & PRE + POS & POS \\
\hline \multicolumn{5}{|c|}{ Grain yield $(\mathrm{GY})\left(\mathrm{kg} \mathrm{ha}^{-1}\right)$} \\
\hline 9/27/2011 & $6973 \mathrm{Bbc}$ & $9237 \mathrm{Aa}$ & $9268 \mathrm{Aa}$ & $9135 \mathrm{Aa}$ \\
\hline $10 / 17 / 2011$ & $8625 \mathrm{ABa}$ & $8031 \mathrm{Bbc}$ & $8451 \mathrm{ABa}$ & $9091 \mathrm{Aa}$ \\
\hline $11 / 8 / 2011$ & $6228 \mathrm{Bc}$ & $8761 \mathrm{Aab}$ & $8996 \mathrm{Aa}$ & $8805 \mathrm{Aa}$ \\
\hline $12 / 5 / 2011$ & $7168^{\mathrm{NS}} \mathrm{b}$ & $7538 \mathrm{c}$ & $7196 \mathrm{~b}$ & $7814 \mathrm{~b}$ \\
\hline \multicolumn{5}{|l|}{ Mean } \\
\hline $\mathrm{CV} \%$ & \multicolumn{4}{|c|}{5.9} \\
\hline \multicolumn{5}{|c|}{ Number of panicles (NP) $\left(\mathrm{m}^{-2}\right)$} \\
\hline 9/27/2011 & $494^{\mathrm{NS}} \mathrm{a}$ & $498 \mathrm{ab}$ & $508 \mathrm{ab}$ & $507 \mathrm{~b}$ \\
\hline $10 / 17 / 2011$ & $531 \mathrm{ABa}$ & $507 \mathrm{Ba}$ & $565 \mathrm{ABa}$ & $623 \mathrm{Aa}$ \\
\hline $11 / 8 / 2011$ & $372 \mathrm{Bb}$ & $407 \mathrm{Bb}$ & $425 \mathrm{Bb}$ & $529 \mathrm{Aab}$ \\
\hline $12 / 5 / 2011$ & $529^{\mathrm{NS}} \mathrm{a}$ & $505 \mathrm{a}$ & $486 \mathrm{ab}$ & $488 \mathrm{~b}$ \\
\hline Mean & 482 & 479 & 496 & 537 \\
\hline $\mathrm{CV} \%$ & \multicolumn{4}{|c|}{10.2} \\
\hline \multicolumn{2}{|c|}{ Times of sowing } & NGP & TGW $(\mathrm{g})$ & $\mathrm{S}(\%)$ \\
\hline \multicolumn{2}{|l|}{$9 / 27 / 2011$} & $74 \mathrm{a}$ & $24 \mathrm{a}$ & $7 \mathrm{bc}$ \\
\hline \multicolumn{2}{|l|}{ 10/17/2011 } & $51 \mathrm{~b}$ & $25 \mathrm{a}$ & $8 \mathrm{ab}$ \\
\hline \multicolumn{2}{|l|}{$11 / 8 / 2011$} & $75 \mathrm{a}$ & $24 \mathrm{a}$ & $6 \mathrm{c}$ \\
\hline \multicolumn{2}{|l|}{$12 / 5 / 2011$} & $53 \mathrm{~b}$ & $22 \mathrm{~b}$ & $9 \mathrm{a}$ \\
\hline \multicolumn{5}{|c|}{ Times of application } \\
\hline \multicolumn{2}{|c|}{ Control group with no application } & $60^{\mathrm{ns}}$ & $24 a b$ & $7^{\mathrm{ns}}$ \\
\hline \multicolumn{2}{|l|}{ PRE } & 62 & $24 \mathrm{a}$ & 7 \\
\hline \multicolumn{2}{|l|}{$\mathrm{PRE}+\mathrm{POS}$} & 63 & $23 \mathrm{~b}$ & 7 \\
\hline \multicolumn{2}{|l|}{ POS } & 66 & $24 a b$ & 8 \\
\hline \multicolumn{2}{|c|}{ Mean } & 63 & 24 & 7 \\
\hline \multicolumn{2}{|c|}{$\mathrm{CV} \%$} & 13.9 & 3.8 & 22.4 \\
\hline
\end{tabular}

Averages not followed by the same letter, lowercase in column and uppercase in row, differ by Tukey test at 5\% probability; Ns not significant in row; ${ }^{n s}$ not significant in column $*$ Doses of imazapic + imazapyr were: $105+35 \mathrm{~g} \mathrm{ha}^{-1}(\mathrm{PRE}),, 52.5+17.5 \mathrm{~g} \mathrm{ha}{ }^{-1}$ and $52.5+17.5 \mathrm{~g} \mathrm{ha}^{-1}$ (PRE+POS), and $105+35 \mathrm{~g} \mathrm{ha}^{-1}$ (POS) 
portion of herbicide to the soil. Thus, part of the herbicides may have been adsorbed on the soil and is not available for uptake by plants (Oliveira et al. 2004).

Corroborating the results of the 2010/11 harvest, sowing date affected grain yield (Table 5), which was higher in the sowing of $09 / 27$, this being the best time of sowing, and lower on $12 / 05$, with an average grain yield of treatments PRE, PRE + POS and POS of 9,213 and $7,516 \mathrm{~kg} \mathrm{ha}^{-1}$, respectively - a decrease of $18.4 \%$, equivalent to $25 \mathrm{~kg}$ ha ${ }^{1}$ day $^{-1}$. These results indicate a larger number of grains per panicle, greater thousand grain weight and lower spikelet sterility occurred at 09/27 (Table 5), due to better conditions of temperature and solar radiation during the reproductive period (Figure 1B, D) compared to the climate conditions of the last date $(12 / 05)$.

In the Philippines, Yang et al. (2008) evaluated the effect of temperature and solar radiation on the weight of grain filling rate and duration of grain filling in different rice genotypes and found a linear increase in yield with increasing temperature and solar radiation accumulated. In Bangladesh, Islam \& Morison (1992) also evaluated the influence of solar radiation and temperature on the yield of rice, and found a positive relationship between grain yield and solar radiation during the reproductive and maturing stages. According to Katsura et al. (2008), high yield is a result of high accumulation of biomass and nitrogen that occurs with high solar radiation availability. Lack et al. (2012) also associated highest yield with grain filling in appropriate temperature conditions.

Thus, sowing date is one of the most important management practices in irrigated rice. However, the isolated use of this practice may not be an important strategy in controlling red rice, and one should then associate sowing time with temperature conditions that hinder the emergence of red rice at the time of sowing to the final irrigation of rice, thus enabling lower emergence of red rice, in addition to matching the reproductive period of the plant with the best weather conditions.

Sowing early in the recommended season provides higher grain yield of rice. The application of imazapic + imazapyr at doses of
$52.5+17.5 \mathrm{~g} \mathrm{ha}^{-1}$ in PRE $+52.5+17.5 \mathrm{~g} \mathrm{ha}^{-1}$ in POS and $105+35 \mathrm{~g} \mathrm{ha}^{-1}$ only in PRE and POS was effective in controlling red rice, but irrigation management must be adequate and with no presence of red rice biotypes resistant to these herbicides.

\section{ACKNOWLEDGEMENTS}

We thank the National Council for Scientific and Technological Development (CNPq), for granting master's scholarship to the first author and for the exchange of research productivity for the second author. The Foundation for Research Support of the State of Rio Grande do Sul (FAPERGS), for granting Scientific Initiation scholarship to the third author. We give thanks to CNPq and FAPERGS for their financial support on the research.

\section{LITERATURE CITED}

ALISTER, C.; KOGAN, M. Efficacy of imidazolinone herbicides applied to imidazolinone-resistant maize and their carryover effect on rotational crops. Crop Protec., v. 24, n. 4, p. $375-379,2005$.

AVILA, L. A. et al. Imazethapyr aqueous photolysis, reaction quantum yield, and hydroxyl radical rate constant. J. Agric.

Food Chem., v. 54, n. 7, p. 2635-2639, 2006.

BRESNAHAN, G. A. et al. Influence of Soil pH-Sorption Interactions on Imazethapyr Carry-over. J. Agric. Food Chem., v. 48, n. 5, p 1929-1934, 2000.

BURGOS, N. R. et al. Red Rice (Oryza sativa) Status after 5 Years of Imidazolinone-Resistant Rice Technology in Arkansas. Weed Technol., v. 22, n. 1, p. 200-208, 2008.

COUNCE, P. A.; KEISLING, T. C.; MITCHELL, A. J. A uniform, objective and adaptive system for expressing Rice development. Crop Sci. Soc. Am., v. 40, n. 2, p. 436-443, 2000 .

EMPRESA BRASILEIRA DE PESQUISA AGROPECUÁRIA - EMBRAPA. Centro Nacional de Pesquisa de Solos. Sistema brasileiro de classificação dos solos. Brasília: Embrapa-SPI, 2006. 412 p.

FIRMINO, L. E. et al. Sorcão do imazapyr em solos com diferentes texturas. Planta Daninha, v. 26, n. 2, p. 395-402, 2008 .

FISCHER, A. J.; RAMIREZ, A. Red Rice (Oriza sativa): competition studies for management decisions. Intern. J. Pest Manag., v. 39, n. 2, p. 133-138, 1993. 
FOGLIATTO, S.; VIDOTTO, F.; FERRERO, A.

Germination of weedy rice in response to field conditions during winter. Weed Technol., v. 25, n. 2, p. 252-261, 2011

FREITAS, T. F. S. et al. Produtividade de arroz irrigado e eficiência da adubação nitrogenada influenciadas pela época da semeadura. R. Bras. Ci. Solo, v. 32, n. 6, p. 2397-2405, 2008.

GEALY, D. R. Emergence of red rice (Oryza sativa) ecotypes under dry-seeded rice (Oryza sativa) culture. Weed Technol. v. 14 , n. 2 , p. $406-412,2000$

GIANINETTI, A.; COHN, M. A. Seed dormancy in red rice. XIII: Interaction of dry-afterripening and hydration temperature. Seed Sci. Res., v. 18, n. 3, p. 151-159, 2008

\section{INSTITUTO NACIONAL DE METEOROLOGIA -} INMET. Capturado em 01 out. 2010 a 01 abr. 2012. Online. Disponível em: http://www.inmet.gov.br/sonabra/ dspDadosCodigo.php?QTgwMw==

ISLAM, M. S.; MORISON, J. I. L. Influence of solar radiation and temperature on irrigated rice grain yield in Bangladesh. Field Crops Res., v. 30, n. 1-2, p. 13-28, 1992.

JAGADISH, S. V. K.; CRAUFURD, P. Q; WHEELER, T. R High temperature stress and spikelet fertility in rice (Oryza sativa L.). J. Exper. Bot., v. 58, n. 7, p. 1627-1635, 2007.

KATSURA, K. The high yield of irrigated rice in Yunnan, China 'A cross-location analysis. Field Crops Res., v. 107, n. 1, p. 1-11, 2008.

KRAEMER, A. F. et al. Persistência dos herbicidas imazethapyr e imazapic em solo de várzea sob diferentes sistemas de manejo. Planta Daninha, v. 27, n. 3, p. 581-588, 2009.

LACK, S.; MARANI, N. M; MOMBENI, M. The effects of planting date on grain yield and yield components of rice cultivars. Adv. Environ. Biol., v. 6, n. 1, p. 406-413, 2012.

MADANI, M. E. et al. pH effect and kinetic studies of the binding behaviour of imazethapyr herbicide on some Moroccan soils. Fresenius Environ. B., v. 12, n. 9, p. 1114-1119, 2003

MARCHESAN, E. et al. Carryover of imazethapyr and imazapic to notolerant rice. Weed Technol., v. 24, n. 1, p. 6-10, 2010.

MARCHESAN, E. et al. Produtividade, fitotoxicidade e controle de arroz-vermelho na sucessão de cultivo de arroz irrigado no Sistema CLEARFIELD ${ }^{\circledR}$. Ci. Rural, v. 41, n. 1, p. 17-24, 2011

MARCOS FILHO, J. Fisiologia de sementes de plantas cultivadas. Piracicaba: Fealq, 2005. 495 p.

Planta Daninha, Viçosa-MG, v. 31, n. 3, p. 631-644, 2013
MERTZ, L. M. et al. Alterações fisiológicas em sementes de arroz expostas ao frio na fase de germinação. R. Bras. Sementes, v. 31, n. 2, p. 254-262, 2009

MORENO, J. A. Clima do Rio Grande do Sul. Porto Alegre: Secretaria da Agricultura, 1961. p. 41.

NOLDIN, J. A.; CHANDLER, J. M.; MCCAULEY, G. N. Seed longevity of red Rice ecotypes buried in soil Planta Daninha, v. 24, n. 4, p. 611-620, 2006.

NORSWORTHY, J. K.; OLIVEIRA, M. J. A model for predicting common cocklebur (Xanthium strumarium) emergence in soybean. Weed Sci., v. 55, n. 4, p. 341-345, 2007.

OLIVEIRA, M. F. et al. Sorção do herbicida imazaquin em Latossolo sob plantio direto e convencional. Pesq. Agropec. Bras., v. 39, n. 8, p. 787-793, 2004

RANG, Z. W. et al. Effect of high temperature and water stress on pollen germination and spikelet fertility in rice. Environ. Exper. Bot., v. 70, n. 1, p. 58-65, 2011.

SANTOS, F. M. et al. Controle químico de arroz-vermelho na cultura do arroz irrigado. Planta Daninha, v. 25, n. 2 , p. 405-412, 2007.

SHIVRAIN, V. K. et al. Red rice (Oryza sativa) emergence characteristics and influence on rice yield at different planting dates. Weed Sci., v. 57, n. 1, p. 94-102, 2009.

SLATON, N. A. et al. Seeding date effect on rice grain yields in Arkansas and Louisiana. Agron. J., v. 95, n. 1, p. 218-223, 2003.

VILLA, S. C. C. et al. Controle de arroz-vermelho em dois genótipos de arroz (oryza sativa) tolerantes a herbicidas do grupo das imidazolinonas. Planta Daninha, v. 24, n. 3, p. $549-555,2006$.

FLINT, J. L.; WITT, W. W. Microbial degradation of imazaquin and imazethapyr. Weed Sci., v. 45, n. 4, p. 586-591, 1997.

YANG, W. et al. Grain filling duration, a crucial determinant of genotypic variation of grain yield in field-grown tropical irrigated rice. Field Crops Res., v. 105, n. 3, p. 221-227, 2008 .

YOSHIDA, S. Fundamental of rice crop science. Los Baños: International Rice Research Institute, 1981. 269 p.

YOUNG-SON CHO. Germination characteristics of Korean and Southeast Asian Redrice (Oryza sativa L.). Seeds as affected by temperature. Asian J. Plant Sci., v. 9 , n. 2 , p. $104-107,2010$ 